\title{
Production of waste polystyrene-based composites and evaluation as corrosion inhibitor for rebar coating
}

\author{
Enes Baş ${ }^{1}$ iD Nihan Akçaer $^{2}$ iD ${ }^{\text {Heydar Dehghanpour }}{ }^{2 *}$, Kemalettin Yılmaz $^{2}$ iD \\ ${ }^{1}$ Gebze Technical University, Engineering Faculty, Civil Engineering Department, Kocaeli, Turkey. \\ ${ }^{2}$ Sakarya University, Engineering Faculty, Civil Engineering Department, Sakarya, Turkey. \\ *heydar.dehghanpour@yahoo.com
}

\begin{abstract}
Corrosion is one of the most effective structural damages in rebar reinforced structural elements. Different methods are applied to protect concrete structures from corrosion. In this study, in order to prevent rebar corrosion, it has aimed to coating recycled polystyrene based composite materials and to examine them with electrical methods. The matrix element in the composites has obtained by dissolving the waste polystyrene foam material in benzine. Carbon, carbon fiber and standard sand were used as additives. Rebar reinforced cylinder concrete specimens, which completed their 28-day age in the curing pool, were subjected to accelerating corrosion by applying 70 Volt voltage in $3 \% \mathrm{NaCl}$ water solution for 48 hours. Anode-cathode and four-probe conductivity measurement tests were performed to determine the corrosion condition of the samples. Splitting tensile test has been performed on the same samples. According to the results, it was found that although the Splitting tensile strength of coated rebar reinforced concrete samples did not change significantly compared to the control sample, all the coatings were advantageous in terms of corrosion prevention. It was also has found that there was good adherence between most rebar and concrete, as understood in the splitting tensile test.
\end{abstract}

Keywords: Corrosion, waste polystyrene, carbon fiber, carbon black, rebar

\section{INTRODUCTION}

Rebar corrosion in reinforced concrete structures is one of the important factors affecting the service life and strength of the structures. Although many structures perform very well, various types of structures in particular in the infrastructure, need significant maintenance due to the impact of aggressive environments [1]. The importance of corrosion in the buildings was seen once more in the 17 August 1999 Marmara Earthquake. The main reason for the corrosion of the reinforcement is the accumulation of chloride ions and carbon dioxide on the steel surface. After the onset of corrosion, corrosion products (iron oxides and hydroxide) generally accumulate around the reinforcement. Formations within this limited area cause damage to the concrete. As a result, the corrosion problem constitutes a large part of the maintenance and repair costs of reinforced concrete structures [2]. Several methods have been applied to prevent corrosion until today. One of these is the galvanizing of the steel rod by hot-dipping. In order to protect the reinforced concrete structures, it is determined that the protection of concrete with low water/cement ratio and hot dip galvanized steel increases the compressive strength and reduces corrosion [3]. The hot-dip galvanized steel 
has great durability and that is the reason why its application in the market grows increasingly. Widely used in metal structures, it can also be an option for reinforced concrete structures [3, 4].

In order to determine the corrosion activity process of steel reinforcement, methods such as polarization methods, electrical resistance method, half cell potential method, acoustic emission method and others are applied $[1,5,6]$.

In this study, corrosion risk is investigated by electrical resistance measurement based on corrosion acceleration method. The corrosion acceleration method has been tested and approved in many studies [3, 7-10]. The corrosion rate of depassivated steel in concrete should be inversely proportional to the resistivity of the concrete [1, 11-14]. In addition, the main purpose of this study is to evaluate the waste material as a composite matrix. Recently, the evaluation of recycled materials such as waste wire [15], waste glass [16] and waste carbon $[17,18]$ in construction materials has been extensively investigated.

\section{MATERIAL AND METHOD}

\subsection{Material}

In this experiment, 18 pieces of $14 \mathrm{~mm} \mathrm{S420}$ ribbed rebar were used. rebar's, cut to $30 \mathrm{~cm}$ in length and were prepared for coating after cleaning. CEM I $42.5 \mathrm{R}$ portland cement was used as the binding material in the mixture of cylinder concrete specimens. 0-4.75 $\mathrm{mm}$ fine sand and 4.75-22 $\mathrm{mm}$ aggregate were used in the concrete mixture. $0.75 \%$ by weight superplasticizer was used in all mixtures. The water : cement : aggregate ratio was kept constant at $0.45: 1: 4$.

In the scope of the study for rebar coatings, polystyrene foam (Fig. 1) which is a waste material has been used as the matrix material and carbon black (CB), carbon fiber (CF) and standard sand (SS) have been used as reinforcement elements. CF is a type of fiber used in building materials for different purposes [19]. SS is a standard aggregate type granulated between 0 and $5 \mathrm{~mm}$. The SS used in the study was passed from the sieve and was fell below $2 \mathrm{~mm}$.

Polystyrene is a material having a lower density than conventional materials and noncellular polymers. It also has superior strength / weight ratio, price suitability, high heat and sound insulation, impact resistance, toughness, fatigue life, thermal stability, low dielectric constant, low thermal conductivity. This polymeric material is used in furniture industry, transportation, bedding, carpet-upholstery, packaging, textile, toys, cap, sports applications, insulation applications. Approximately $200 \mathrm{~g}$ of polystyrene foam was dissolved in $200 \mathrm{~g}$ of benzine to give the resin consistency.

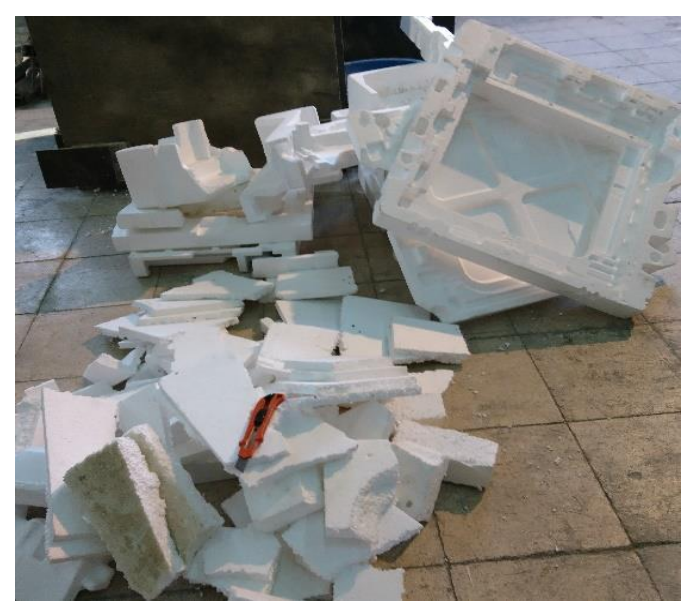

Fig. 1. Waste polystyrene foam. 
Carbon fibers are materials with high modulus and strength of elasticity, low unit weight and resistant to environmental conditions [20]. CB used in composite mixture is a by-product obtained by pyrolysis method from waste tires [17]. Polystyrene matrix in composites was obtained by dissolving the polysterene foams by immersing them in benzine.

By combining the above-described materials in different ratios, 9 different polystyrene-based composite materials were produced (Table 1).

Table 1. Content of coating composites.

\begin{tabular}{cllll}
\hline Specimen No & \multicolumn{5}{c}{ Polystyrene, \% } & CB, \% & CF, \% SS, \% \\
\hline 1 & 100 & 0 & 0 & 0 \\
2 & 90 & 10 & 0 & 0 \\
3 & 98 & 0 & 2 & 0 \\
4 & 50 & 0 & 0 & 50 \\
5 & 88 & 10 & 2 & 0 \\
6 & 40 & 10 & 0 & 50 \\
7 & 48 & 0 & 2 & 50 \\
8 & 38 & 10 & 0 & 50 \\
9 & & 10 &
\end{tabular}

Two coated rebar specimens were produced from each composite by applying the composite materials to the previously prepared $30 \mathrm{~cm}$ rebar specimen surfaces. 9 produced composite materials and their application to the rebar surfaces is shown in Fig. 2. The coating thickness was adjusted to an average of 2 $m m$.

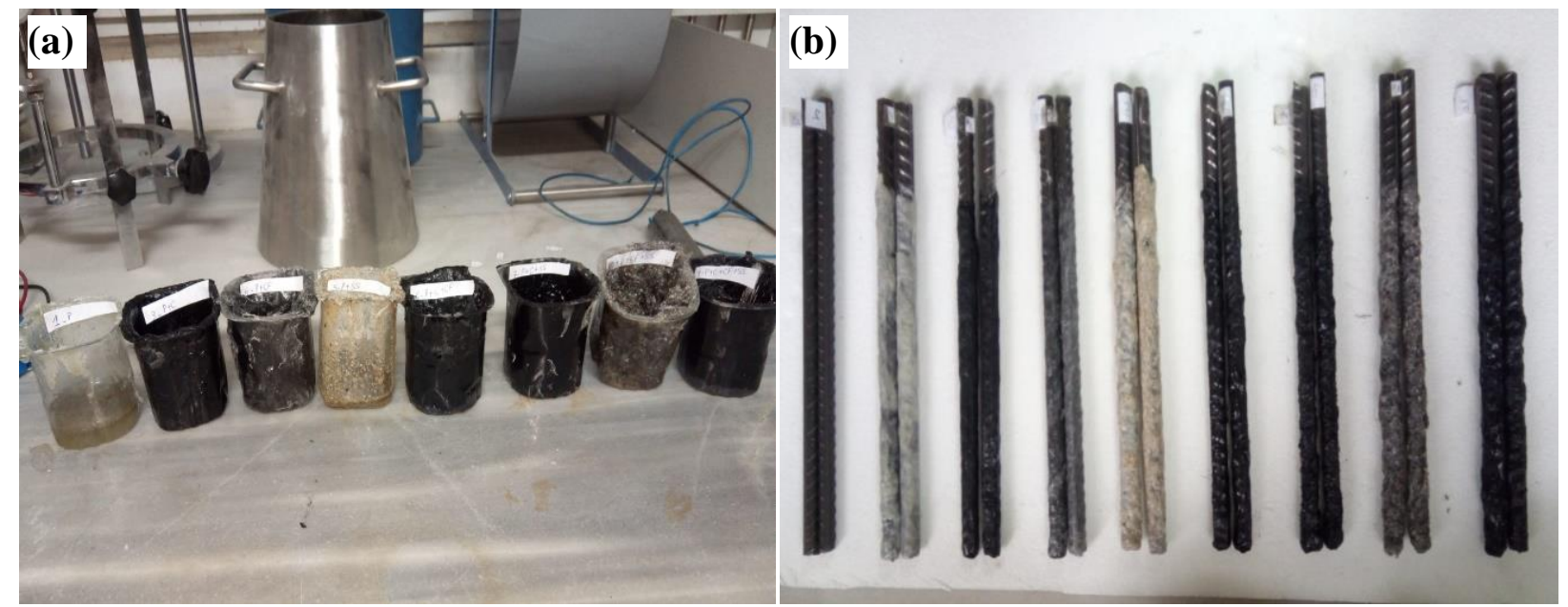

Fig. 2. produced composite materials (a) and their application to the rebar surfaces (b).

For corrosion acceleration tests, a total of 18 cylindrical specimens were obtained, two of each composite, using coated rebar in the concrete mixture which details given above. For all samples, concrete type with single mixture design was used.

In order to determine the compressive strength of the produced concrete, 3 pieces of $10 \times 10 \times 10 \mathrm{~cm}$ cubic specimens were produced. All specimens were stored in the curing pool for 28 days and then were prepared for the experiment as seen in Fig. 3. 


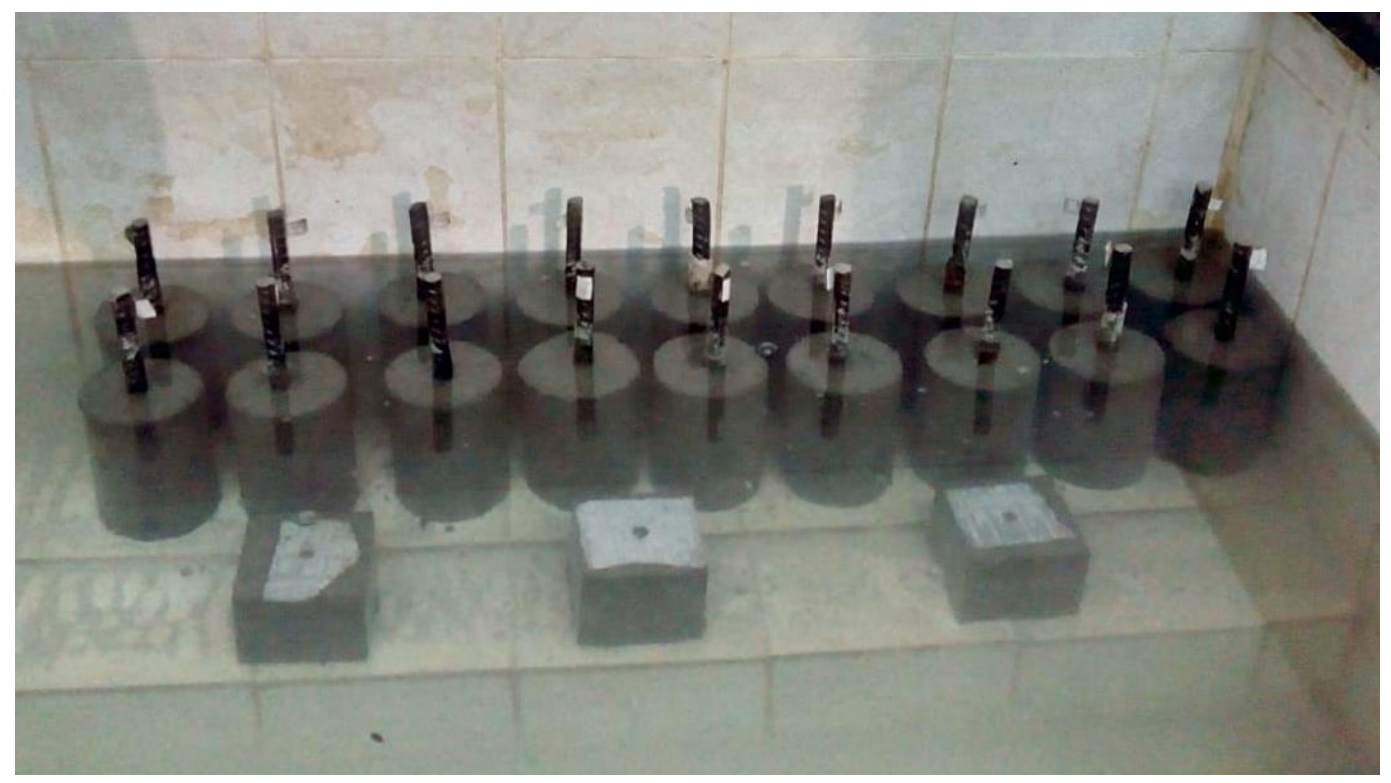

Fig. 3. Curing process of specimens.

\subsection{Test Methods}

Anode-cathode method was used for corrosion acceleration in the specimens. In this method, as shown in Fig. 4, reinforced concrete sample is put into $3.5 \% \mathrm{NaCl}$ solution. In the solution, a conductive rod or plate is placed on the other side. The rebar in the reinforced concrete is connected to the positive side of the power supply and the conductive plate to the negative side of power supply. Corrosion acceleration process continues for 48 hours by applying $70 \mathrm{~V}$ potential difference.

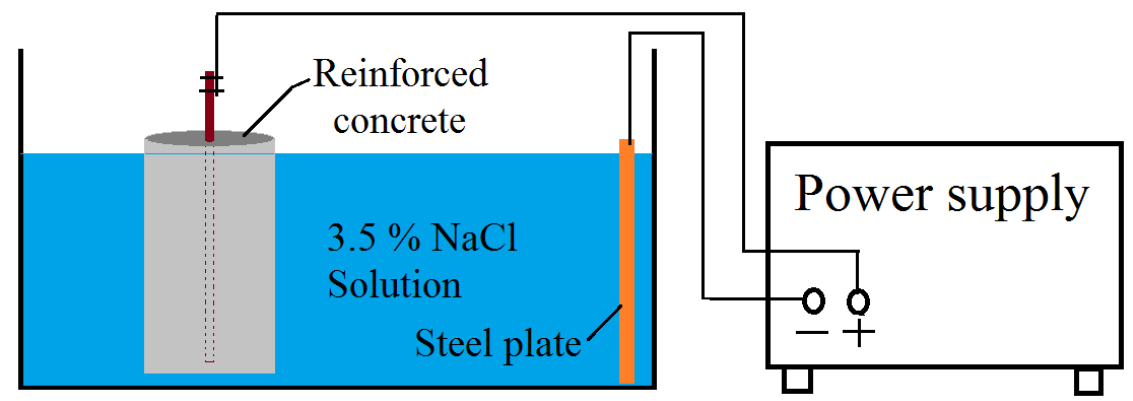

Fig. 4. Schematic image of corrosion acceleration device.

After the acceleration of corrosion, the corrosion levels of the specimens were examined by two different methods. Four-Probe and one electrode current measurement methods. Schematic views of the Four-probe and one electrode current measurement methods are given in Fig. 5.

(a)

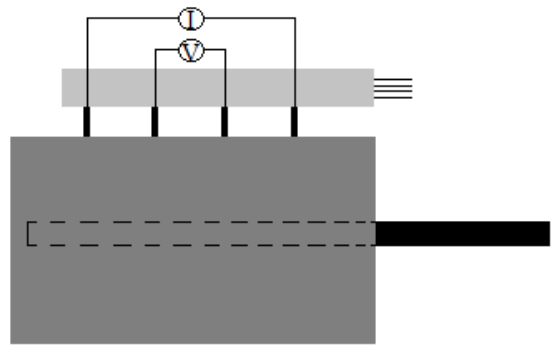

(b)

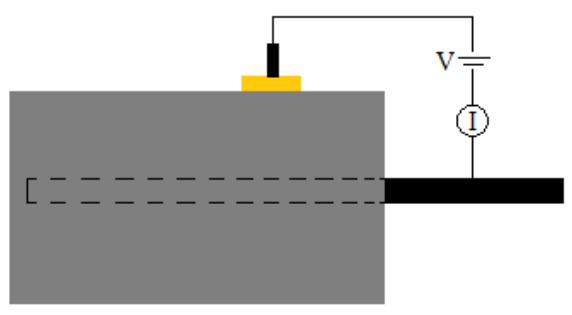

Fig. 5. Schematic views of the Four-probe (a) and one electrode (b) current measurement methods. 
In the four-probe method, a certain voltage is applied between the two inside probes of the instrument which are placed on the concrete surface. The amount of current occurring between the two external probes is measured. Resistance $(R)$ value is obtained from equation 1 . Then, equation 2 is used to calculate the resistivity.

$$
\begin{aligned}
& V=I . R \\
& \rho=2 . \pi \cdot \mathrm{a} . \mathrm{R}
\end{aligned}
$$

In these equations, $V$, voltage, $I$, current in amperes, $R$, resistance in $\Omega, \rho$, resistivity in $\Omega . c m$ and a, is the distance between the probes in $\mathrm{cm}$.

In the one electrode method, as shown in Figure 5.b, the current value between the rebar and the concrete is measured after applying a certain voltage. The resistance $(R)$ value is obtained from equation 1 and equation 3 is used to calculate the resistivity.

$$
\rho=2 \cdot \mathrm{a} \cdot \mathrm{R}
$$

In the splitting tensile test method, two bar is placed horizontally below and above of cylinder concrete sample. the cylinder sample is loaded horizontally until it is broken by the press device. In this test method, split-tensile strength is obtained from equation 4.

$$
\sigma_{s t}=\frac{2 P}{\pi \cdot d \cdot l}
$$

Where $P$ is the maximum load measured in $P a, \mathrm{~d}$ is the cylinder sample diameter in $\mathrm{mm}$ and $\mathrm{l}$ is the sample length in $\mathrm{mm}$.

\section{RESULT AND DISCUSSION}

The corrosion acceleration process of the specimens is shown in Fig. 6a. In this study, all cylinder specimens were connected to the positive direction of the power supply and the plates in the solution were connected to the negative side of the power supply. After applying a voltage of $70 \mathrm{~V}$ for 48 hours, rust precipitation can be seen from the figure to the bottom of the solution. Many parts of the collapsed rust may belong to uncoated rebar's, as understood from the subsequent results.

After corrosion acceleration, surface changes of all specimens were examined. No cracks were formed on the surface of any specimen except the uncoated rebar reinforced specimen. The capillary cracks that occur on the surface of the uncoated rebar reinforced specimen after the process are also seen in Fig. 6b. The reason for the cracks is the increase in volume caused by the rusting of the rebar.

In this study, investigations between specimens are based on the resistance measurement method described in the previous section. Resistance values of all samples were obtained in both one-electrode and four-point method using equation 1 (Fig. 7). As can be seen from the figure, the four-point resistance values are approximately 4.5 times the one-electrode resistance values. This situation regarding the resistance of concrete, i.e. the difference between the resistance values measured by two different methods, has been determined in previous studies. The maximum and minimum values measured by the four-point method belong to sample 9 as $2904 \Omega$ and to sample 1 as $726 \Omega$, respectively. Also, the maximum and minimum values measured by the one-electrode method belong to sample 5 as $642 \Omega$ and to sample 1 as $193 \Omega$, respectively. 

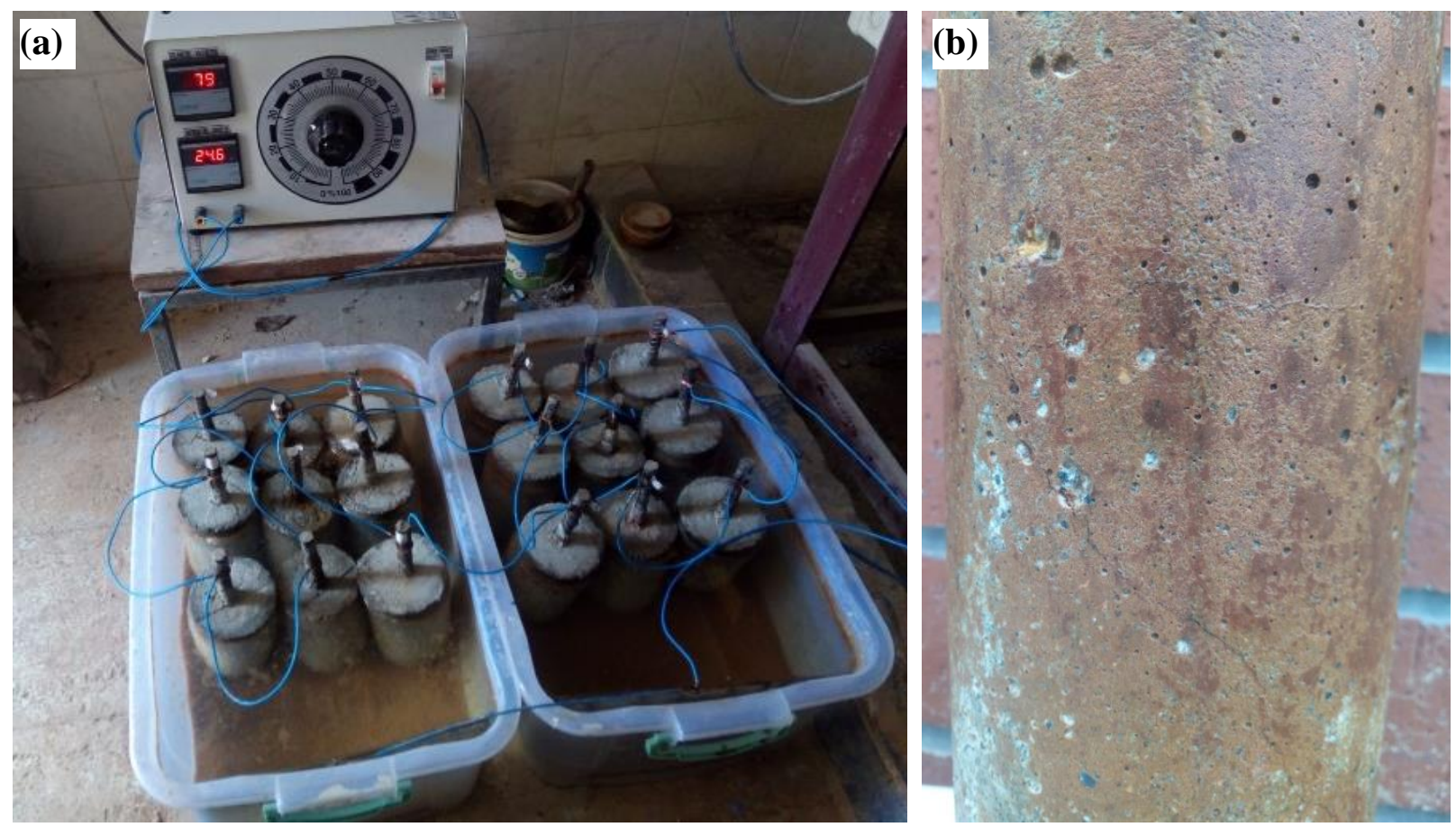

Fig. 6. The corrosion acceleration process of the specimens (a) and surface of the uncoated rebar reinforced specimen after the corrosion acceleration process (b).

In general, the resistance values of the reinforced concretes with all coated samples, except the uncoated sample, were measured very close to each other. In both methods, the resistance values of the coated samples increased by more than 3 times compared to the resistance value of the uncoated specimen.

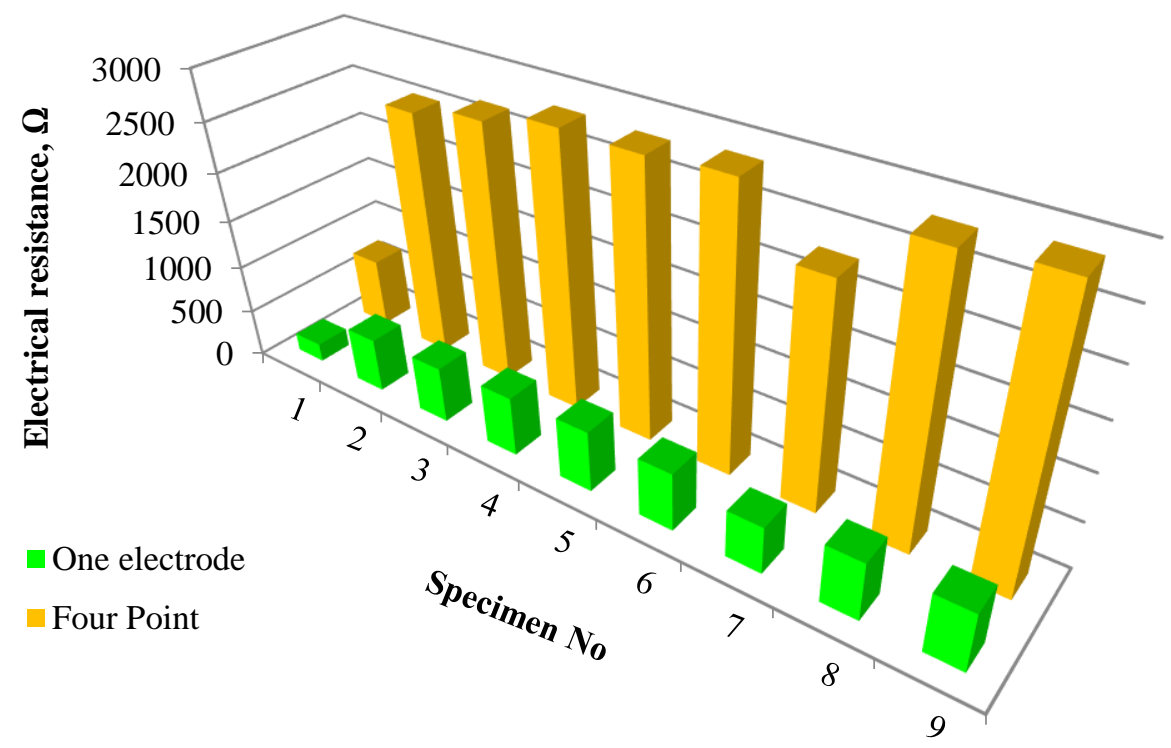

Fig. 7. Resistance results measured by two different methods.

After measuring resistance, splitting tensile tests of all cylinder specimens were performed. According to the results, split-tensile strength average as $2.2 \mathrm{MPa}$ similar values were obtained. In addition, the compressive strength of the cube samples produced from the concrete mixture was obtained as $26.5 \mathrm{MPa}$. According to the literature, the compressive strength and split-tensile strength of the specimens in this study 
are compatible [21]. The split-tensile test results are summarized in Fig. 8. The maximum split-tensile strength values, as $2.54 \mathrm{MPa}$, belong to specimens 6 and 7. Resistance values of specimen 6 were measured as $2882 \Omega$ and $2310 \Omega$ by four-point and one-electrode methods, respectively, and Resistance values of specimen 7 were measured as $610 \Omega$ and $493 \Omega$ by four-point and one-electrode methods, respectively.

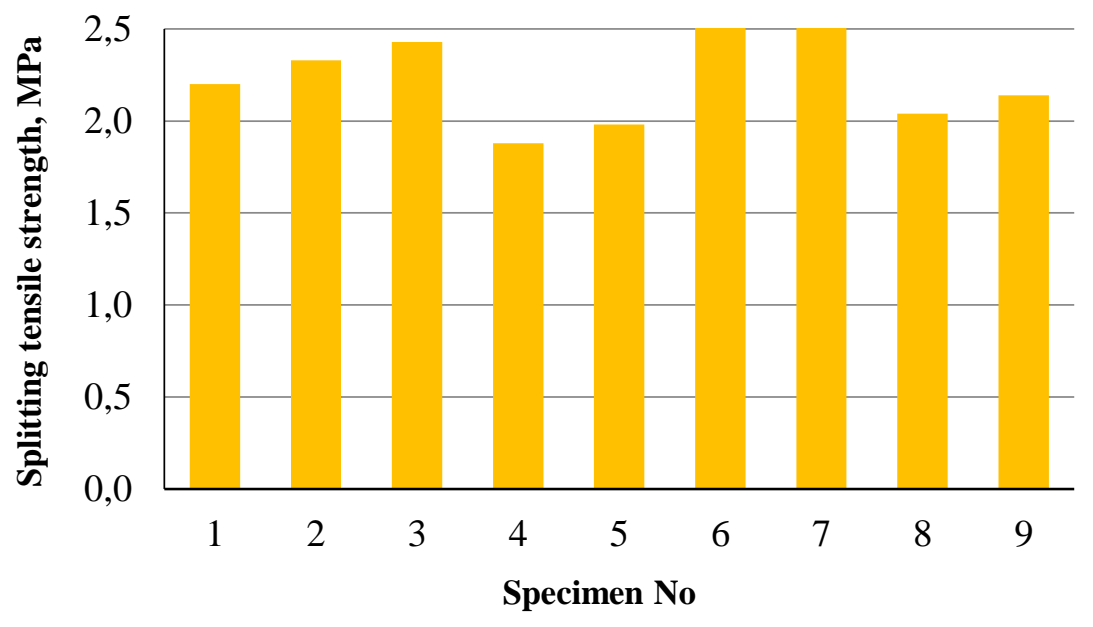

Fig. 8. The split-tensile test results of specimens.

Fig. 9 shows the adherence state (a) of specimen- 6 and the mass loss (b) of the uncoated specimen. $A$ good bond between rebar and concrete in specimen- 6 was found after the split-tensile test. It is understood from the above results also that specimen- 6 is corrosion resistant.

Fig. 9 shows the loss of mass of the uncoated rebar clearly. The mass loss was calculated as $2.05 \%$ by weighing the first weight of the rebar and the weight after corrosion acceleration. In addition, there was no mass loss in the other specimens.
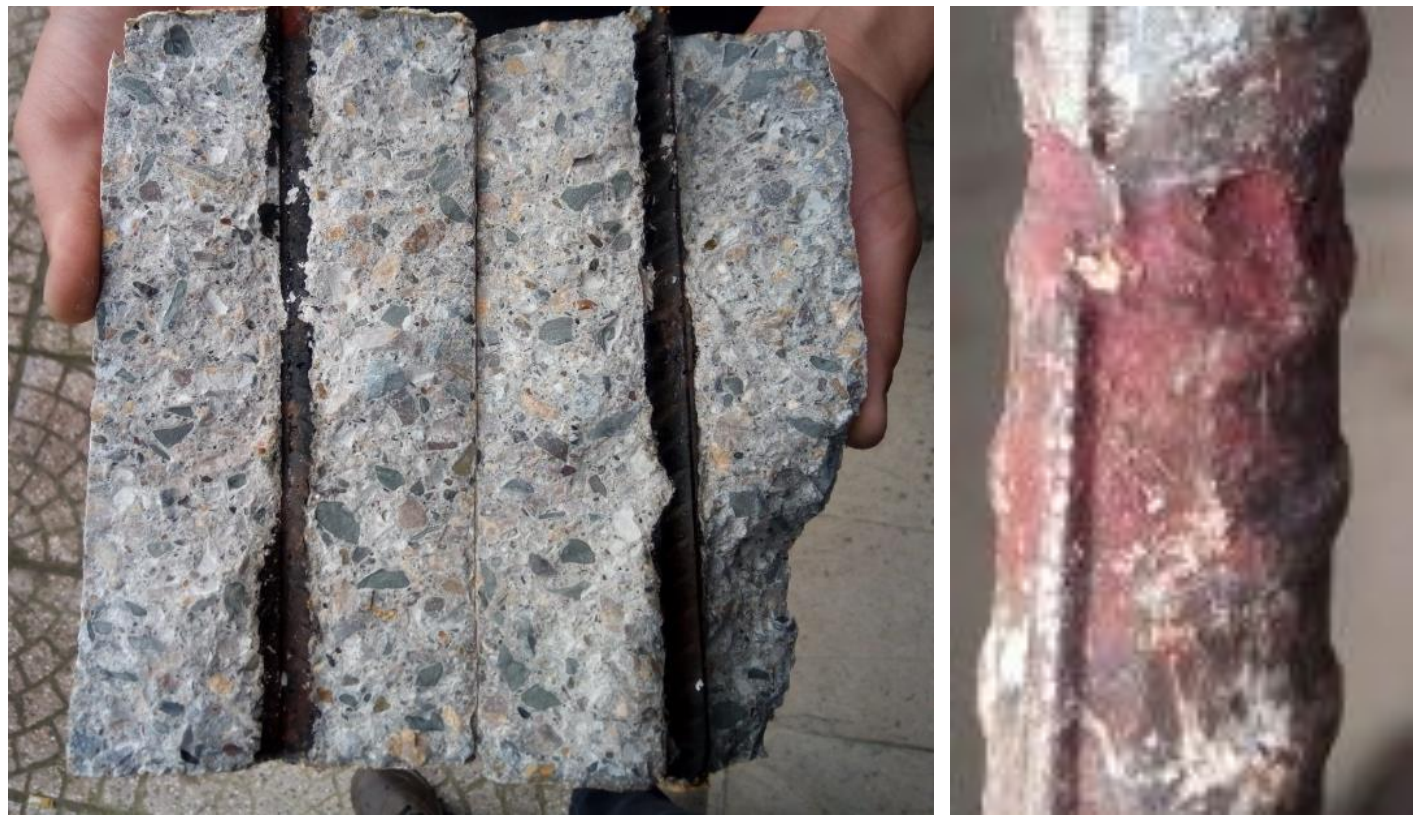

Fig. 9. the adherence state (a) of specimen-6 and the mass loss (b) of the uncoated specimen. 


\section{CONCLUSIONS}

In this study, anti-corrosion composites were produced by using different ratios of waste polyester, $\mathrm{CF}, \mathrm{CB}$ and SS. Corrosion status of the specimens were investigated by two different resistance measurement methods as four-point and one-electrode methods. After corrosion detection, all specimens were subjected to split-tensile test. The main results of the study are given below.

By applying a voltage of $70 \mathrm{~V}$ for 48 hours, there were no defects on the surface of the other specimen except the uncoated specimen. On the surface of the uncoated rebar reinforced concrete, significant cracks have occurred due to the volume increase. This, occurs when a rust layer forms on the surface of the rebar and creates pressure inside the concrete.

Resistance values measured by four-point method were obtained as approximately 4.5 times the resistance values measured by one-electrode method. This has been confirmed by previous studies in the literature. In the four-point method, it obtains information about the surface resistance of the concrete specimen. Therefore, the amount of electrical current measured by this method may be less than the amount of current measured by the one electrode and bulck methods.

The maximum and minimum values measured by the four-point method belong to sample 9 as $2904 \Omega$ and to specimen 1 as $726 \Omega$, respectively. Specimen 9 contains $38 \%$ polystyrene $10 \% \mathrm{CB}$ and 50\% SS. Therefore, corrosion was prevented by covering the SS and the pores between them CB on the rebar surface. Also, the maximum and minimum values measured by the one-electrode method belong to specimen 5 as $642 \Omega$ and to sample 1 as $193 \Omega$, respectively. In this method, the most resistant to corrosion is composite containing 50\% polystyrene and 50\% SS. The only difference with the result of the previous method is the $\mathrm{CB}$ deficiency. Actually, the presence of $\mathrm{CB}$ is expected to be anticorrosive. Therefore, the misleading result in this method may be due to mistakes during coating.

According to the results, split-tensile strength average as $2.2 \mathrm{MPa}$ similar values were obtained. In addition, the compressive strength of the cube samples produced from the concrete mixture was obtained as 26.5 $M P a$. From split tensile test, it is concluded that the amount of standart sand is getting increased, the strength of composite decreases. Its main reason is that.

The mass loss was calculated as $2.05 \%$ by weighing the first weight of the rebar and the weight after corrosion acceleration. In addition, there was no mass loss in the other specimens. The loss of mass is due to the uncoated rebar being weak against corrosion. however, since all coated rebars are resistant to rust, there was no mass loss.

As a result, according to all the data obtained from this study, the composite material used in specimen-6 is suggested as the most suitable composite material. The resistance values of this sample measured by four-point and one-electrode methods are $2882 \Omega$ and $610 \Omega$, respectively.

\section{ACKNOWLEDGEMENTS}

The authors would like to thank the civil engineering department of Sakarya University for their technical support. 


\section{REFERANSLAR}

[1] Polder, R.B., Test methods for on site measurement of resistivity of concrete - a RILEM TC-154 technical recommendation. Construction and building materials, 2001. 15(2-3): p. 125-131.

[2] Delikanlı, F., Donatılı Betonda Korozyon Hasarı ve Giderilme Yolları. 2001, Fen Bilimleri Enstitüsü.

[3] de Kayser Ortolan, V., Hilgert, T., Howland, J.J., Silva Oliveira, L.F., and Fonseca Tutikian, B., Comparative assessment of corrosion of concrete reinforced with unprotected steel and hot-dip galvanized steel. 2017.

[4] Baltazar-Zamora, M., Bandala, E., Tello, M., Hurtado, G., Coca, F., Cedano, A., Barrios, C., Nuñez, R., Zambrano, P., and Tiburcio, C., Efficiency of Galvanized Steel Embedded in Concrete Previously Contaminated with 2, 3 and 4\% of $\mathrm{NaCl}$. International Journal of Electrochemical Science, 2012. 7: p. 29973007.

[5] Polder, R., Andrade, C., Elsener, B., Vennesland, Ø., Gulikers, J., Weidert, R., and Raupach, M., Test methods for on site measurement of resistivity of concrete. Materials and Structures, 2000. 33(10): p. 603611.

[6] Glass, G., Page, C., and Short, N., Factors affecting the corrosion rate of steel in carbonated mortars. Corrosion Science, 1991. 32(12): p. 1283-1294.

[7] Graeff, Â.G., Avaliação experimental e modelagem dos efeitos estruturais da propagação da corrosão em elementos de concreto armado. 2007.

[8] Lima, R.C.A.d., Investigação do comportamento de concretos em temperaturas elevadas. 2005.

[9] Torres, A., Avaliação da sensibilidade do ensaio CAIM-corrosão acelerado por imersão modificada-frente ao processo de corrosão. Porto Alegre: PPGEC/UFRGS, 2006.

[10] Tutikian, B.F. and Ortolan, V., Comparação da resistência à compressão, da perda de massa e visual entre inibidores de corrosão para prismas de concreto armado. Ciência \& Engenharia, 2014. 23(1): p. 01-08.

[11] Polder, R.B. and Peelen, W.H., Characterisation of chloride transport and reinforcement corrosion in concrete under cyclic wetting and drying by electrical resistivity. Cement and Concrete Composites, 2002. 24(5): p. 427-435.

[12] Raupach, M., Chloride-induced macrocell corrosion of steel in concrete-theoretical background and practical consequences. Construction and building materials, 1996. 10(5): p. 329-338.

[13] Dunn, R.C., Ross, R.A., and Davis, G.D., Corrosion monitoring of steel reinforced concrete structures using embedded instrumentation. CORROSION 2010, 2010.

[14] Pour-Ghaz, M., Isgor, O.B., and Ghods, P., The effect of temperature on the corrosion of steel in concrete. Part 1: Simulated polarization resistance tests and model development. Corrosion Science, 2009. 51(2): p. 415-425.

[15] Dehghanpour, H. and Yilmaz, K., Mechanical and Impact Behavior on Recycled Steel Fiber Reinforced Cementitious Mortars Scientific Herald of the Voronezh State University of Architecture \& Civil Engineering., 2018. 39(3).

[16] Dehghanpour, H. and Yılmaz, K., Evaluation and Investigation of Waste Glass Aggregates and Powders in Architectural Mortars. Scientific Herald of the Voronezh State University of Architecture \& Civil Engineering., 2019. 44(4).

[17] Dehghanpour, H., Yilmaz, K., and Ipek, M., Evaluation of recycled nano carbon black and waste erosion wires in electrically conductive concretes. Construction and Building Materials, 2019. 221: p. 109-121.

[18] Dehghanpour, H. and Yilmaz, K., Microstructure Characterization of Nano Carbon Black Obtained by Combustion Method for Use in Concrete, in ISLAC'18. 2018.

[19] Dehghanpour, H., Afshari, F., and Yılmaz, K., ABAQUS Modeling and Investigation of Nuclear Central Cooling Tower Reinforced by CFRP. ALKÜ Fen Bilimleri Dergisi: p. 59-70. 
[20] DEMIREL, B. and GÖNEN, T., Karbon fiber takviyeli betonda farkli fiber boyunun kapilariteye etkisi. Firat Üniversitesi Doğu Araştırmaları Dergisi, 2007. 6(1): p. 12-15.

[21] Chan, S.Y., Peng, G.-f., and Chan, J.K., Comparison between high strength concrete and normal strength concrete subjected to high temperature. Materials and Structures, 1996. 29(10): p. 616. 